\title{
TELL TALE INCREASING SKILL: INCREASING INDONESIAN STUDENT READING COMPREHENSION THROUGH INDONESIAN FOLKLORE
}

\author{
Endang Ernawati $^{1}$; Retnowati ${ }^{2}$ \\ ${ }^{1,2}$ English Departement, Faculty of Humanity, Bina Nusantara University \\ Jl. Kemanggisan Ilir III No. 45. Kemanggisan, Palmerah, Jakarta Barat, 11480 \\ 1ernawa@binus.edu; ${ }^{2}$ retnowari_pareanom@yahoo.com
}

\begin{abstract}
The goals of the research were to compile a reading material that was able to measure the fifth year primary students' comprehension to the Betawi folklore which represented Indonesian culture; the value found in the Betawi folklore, and to increase their writing skills based on the vocabulary in context assessment. A library research was applied by selecting the story suitable for primary school students, translating materials, simplifying the reading, and making reading exercise to develop student's reading comprehension skills. Reading materials and exercises were focused to the fifth year primary students who have been learning English for more than three years. It can be concluded that the interesting reading materials can be compiled from the original Indonesian folklore entitled "The Old Sly Stork" to support students' achievement in finding the story's values, and students' skills in writing based on the reading materials, value, and their daily life experiences.
\end{abstract}

Keywords: increasing skills, student skills, reading comprehension, folklore

\section{INTRODUCTION}

It is a fact that there is a lack of interest of reading in Indonesian culture. Some of the causes of the lack of reading habit are culture and the presence of technology such as internet, television, video game, and so forth. Indonesian culture is orally culture based. The work of Indonesian traditional literature, including children literature, has been told orally since long time ago, so the children know the story of their parent's storytelling. Some of the stories are now written and also translated into English, but only some students know them because of their lack of reading. Based on the 2003 PISA (Programme for International Students Assessment) results, Indonesian students did not do well in three areas-reading, mathematics, and science compared to highly literate countries such as Finland, South Korea, and Hong Kong (Dursin, 2009).

This lack of reading becomes the concern of the librarians as Desi Anwar, a guest speaker at a national seminar on library and archives, noted how disappointed the librarians are about the poor reading habits of children in Indonesia and what should be done by those librarians to encourage the children to read more. A reading habit, after all, is essential in raising well-informed individuals and yet, it is difficult to get the children to develop a love for books, especially with the presence of television, video games, the internet, and other distractions (2013).

Wahyuni in Voices of Youth (2014) has written that the percentage of interest in reading and writing in the English journal in Indonesia is only 10\%. This is far behind Singapore in which the interest in writing and reading reaches $18 \%$ of the total population while Malaysia at $20 \%$ (based on the data fromThe Indonesian Institute of Sciences or LIPI). Those things indicate why Indonesians need to learn English. The best way to learn is when the students can feel and actively participate since 
the students know that making mistakes becomes a way to learn, and when the students can use English not only in a test but also in their environment as an international social intercourse. Learning English nowadays is a must as a handle to strengthen skills in various sectors. Indonesian folklore as part of Indonesian cultures can be used as a mean of increasing reading habit as well as learning English through their translation into English.

There are various Indonesian folklores as part of children literature based on the tribes and area where they come from. The characteristic of children literature such as the easy storyline and having moral values are the factors that can make children eager to read.

In every culture, folklore plays a significant role. It refers to the traditional belief and the story of the community that is passed down from one generation to the other through word of mouth. Folklore includes folktales, myths, legends, beliefs, practices, superstition, etc. This highlights that folklore captures a wide span. It can even be stated that folklore of a particular group of people is built in accordance with their culture. People make sense of their surrounding world through the usage of folklore. The various superstitions, stories, beliefs all add up to the creation of this cultural heritage.

This research focuses on how to compile reading and exercise materials based on a Betawi folklore, entitled Bangau Tua yang Licik (The Old Sly Stork) to increase the reading comprehension of the students as well as to improve their English skills through understanding the English stories. It is one of the Betawi folklore published by Jakarta.go.id.

The research explored three problem formulations, as follows: (1) How to compile the Betawi folklore into English reading materials suitable for the 5th of primary students'; (2) How to prepare the English Reading exercises; (3) How to develop the writing skills of the 5th year of primary students based on their reading comprehension?

The scope of the research is reading comprehension skills development by using Indonesian folktales, and the limitation of the research is the folklores, entitled Bangau Tua yang Licik (The Old Sly Stork). The folklore comes from the book entitled Cerita Rakyat Betawi, published in 2004 by Dinas Kebudayaan dan Permuseuman, Dinas Pariwisata dan Kebudayaan, Provinsi DKI Jakarta. The limitation is vocabulary in the context comprehension. The goals of research ae to find out: (1) the way to compile the English reading materials translated from Betawi Folklore; (2) the assessment of English Reading materials for the 5th of primary students in developing their reading comprehension; (3) the way the students are able to expand their writing skills based on their reading comprehension materials.

In learning English as a second or foreign language, Anderson (1982) has asserted that reading is the most important skill to master. The reading materials which are used can range from the easy to the difficult ones. Children's literature can be used as the material to improve the English skills as well as the reading habit. Using children's literature can be an effective and enjoyable way to teach the language. Students who are enthralled by a story forget their worries and anxieties about the new language. In an interview with Tova Ackerman, storyteller DvoraShurman, has said that "The best way to teach is not to impose teaching, but to allow the listener to become so involved in hearing a story that his 'defenses' are no longer active". It is our sense of enjoyment, excitement, and emotional involvement that is a necessary condition for learning, and using literature in the classroom can provide the content base for the magic (Ackerman, 1994).

Children literature can be categorized as realism, fiction, nonfiction, fantasy, traditional literature, and poetry (Brown, 2001). Traditional literature is a story which is based on tradition. The creator and when it was created is unknown. From generation to generation, it has been told by word of mouth. The category of traditional literature covers folktales, fables, myths, legends, epics, and traditional poem (Burhan, 2003). 
Folklore is about all prose narrative following traditional storylines, using word of mouth, or is so told in previous generations. It includes fairytales, legends of all types, memorates, fables, tall tales and humorous anecdotes. The original author is always unknown. Indonesian culture produces many kinds of folklore. They are variously based on the tribes and the areas where the folklore comes from. The characters in folklore would be the mirror of human life in the society (Hendra, 2013).

Some of the traditional literature or folklore are now written, and some are translated into foreign languages such as English. The characteristics of the folklore are (a) truth and justice-defeating evil, (b) although the crime is covered up will be uncovered as well, (c) a crime or truth, respectively each will reap the results, (d) true love requires sacrifice, (e) real friends are coworkers in grief, (f) after suffering an afterthought of God, (g) someone should take the trouble first and then going to have fun.

Referring to the characteristic above, folklores can be used as an effort to develop and to create an environment of expression, imagination, and learning that allows children to be able to explore, assess, apply the concepts and moral values, and familiarize themselves the virtuous character in daily life (Supartinah, 2007). Since the folklores will be translated into English, they can be the means of introducing the Indonesian culture as well as improving the skill of children in English. When the children know the ideas of their own culture, they would be able to guess the meaning of the English words.

\section{METHODS}

The research applies a qualitative research with the type of library research. Materials taken for making reading materials is a Betawi folklore, entitled Bangau Tua yang Licik is taken from a book entitled Cerita Rakyat Betawi, published in 2004 by Dinas Pariwisata dan Kebudayaan Provinsi DKI Jakarta from Jakarta.go.id. Bangau Tua yang Licik is chosen because it is a kind of fable, in which a story is having animal characters that the students are interested in. The students' interests are hoped to be able to motivate students in understanding the story, and finally, they can comprehend and develop their writing skills.

The Betawi folklore is chosen to develop students' awareness and pride to local stories in which they seldom read now. Instead, they are flooded by western stories that are easily absorbed their attentions. It is not really bad, but learning our own culture to develop students' reading skills must be in the balance with learning reading skills through the famous western folklore, such as The Grimm's fairy tales: The Frog King, Cinderella, Little Red Cap, etc.

Data compilation indicates that after finding the folklore, it is translated into English and simplified. Data analysis is done by simplifying the translated folklores into a short narration and prepared for a reading materials by making the simple plot based on the story, choosing the appropriate and interesting vocabulary suitable for the 5th-grade students, preparing materials for class exercise to develop students' reading comprehension skills. Another reason for choosing the folklore is because it has a simple plot. The simple way of telling stories of folklore will enable students to understand the English words. From that work of literature that is already simplified and translated into English, the students can easily understand the content because the characteristics and symbols in the story are familiar to them, especially they come from the same regions.The media to enable students to write can be visual aids such as drawing, picture, and cards, related to the stories. The teachers provide the English words and ask the students to re-arrange the sentences in English. By doing so, two goals which are increasing reading habit and English skill are fulfilled. 
The expected results indicate that the reading materials translated from the local story will enable students to understand the context and it is easier for them to transfer their ideas into English. Illustrations should be interesting and help students understand both the vocabulary and the story. Since the story is translated into English, it is easier for the study of English words because they know the context.

The lack of reading habit can be minimized by encouraging the students to read the books about Indonesian folktale which are easy to read and represent the Indonesian culture. The rich of work of Indonesian literature, especially folktale is an important aspect which may be the source to increase the reading comprehension skills in English. By understanding the context of the story, the students easily understand the difficult words since they refer to their origin they are familiar with.

\section{RESULTS AND DISCUSSIONS}

The Following is the original text of Bangau Tua yang Licik and its translation entitled the Sly Old Stork (Figure 1) done by the writers.

\section{Bangau Tua yang Licik}

Di atas dahan pohon yang rindang, si tua bangau tong-tong memperhatikan air telaga di hadapannya. Ikan-ikan besar, kecil tampak berenang-renang dengan elok-eloknya. Bangau tong-tong hanya mampu menelan liurnya. Perutnya keroncongan minta diisi, namun ia terlalu tua untuk memburu ikan-ikan di telaga yang jernih itu. Tiba-tiba paruh si tua bangau mendongak ke langit. Ia baru saja mendapat satu akal bulus. Suatu cara untuk mendapatkan ikan tanpa harus mengejarngejar mereka.

"Hai kawan-kawan", Si Bangau berseru-seru, "Kemarau segera akan tiba."

"Heh, apa pedulimu," ujar si Gabus.

"Semua juga tahu kemarau pasti datang", sahut Si Ketam.

"Sudah, tak perlu hiraukan si tua pandir itu" si Lele berkata ketus.

"Tunggu kawan-kawan," seru Bangau, "Kemarau kali ini akan berlangsung lama, telaga ini akan mengering".

"Apaaa?" seru semua hewan penghuni telaga kaget.

"Ya kawan-kawan telaga ini akan mengering".

Ketakutanlah semua hewan penghuni telaga itu. Ada yang menangis, ada yang mengumpulkan anak istrinya dan ada juga yang mengumpulkan harta bendanya. Mereka semua berenang-renang tak tentu arah.

"Tenang kawan-kawan tenang," ujar Bangau, "Aku tahu sebuah telaga yang luas di kaki bukit, telaga itu tak pernah kering walau kemarau sangat panjang."

"Telaga-telaga kepalamu", "bentak Si Gurami, "Kau pikir kami akan terbang ke sana?"

"Itulah yang kumaksud sobat", ucap bangau, "Kalau kau mau aku bisa membawamu terbang ke sana" "Sungguhkah?" sambut ikan mas tertarik.

"Tentu saja" jawab si Bangau,"Apapun akan kulakukan demi membantu teman".

"Bawa kami paman, bawa kami", seru hewan penghuni telaga dengan riuhnya.

"Tenang-tenang, tak perlu berebut. Aku akan membawa kalian satu persatu."

Kemudian si Bangau menghampiri kumpulan ikan. Dengan paruhnya ia mengangkat seekor ikan mas yang sedang besarnya. Lalu terbanglah bangau tong-tong itu dengan ikan mas di paruhnya. 
Seharian itu berulang-ulang si bangau mengambil ikan dan berbagai hewan air lain dari telaga itu. Menjelang senja semua ikan telah terangkat habis. Tinggallah si Ketam sendirian.

Si Ketam menoleh kiri kanan. Sudah tak ada teman seekor pun. Pikir si Ketam tentu mereka sudah senang di telaga besar di kaki bukit seperti janji si Bangau.

Tak berapa lama si Bangau kembali. Ia memandang berkeliling, tak ada ikan lagi yang nampak. Bangau tersenyum puas, perutnya kenyang sekali. Ia lalu hinggap di dahan pohon.

"Paman bangau, jangan lupakan aku", suara parau si Ketam membangunkan si Bangau.

"Hmm, kaukah itu Ketam?"

"Ya paman, bawa juga aku ke telagamu itu, tolonglah paman di sini aku sendirian sekarang".

"Hmm, kaukah itu Ketam?"

"Ya paman, bawa juga aku ke telagamu itu, tolonglah paman di sini aku sendirian sekarang".

Si Bangau menatap Ketam. Tak banyak daging ketam itu tentunya. Lagi pula Bangau telah kenyang makan ikan penghuni telaga. Namun, si Bangau memang tamak, pikirnya, Ketam itu cukup nikmat untuk hidangan penutup.

"Baiklah sobat kecil," ujar si Bangau, "Mari kubawa kau ke telagaku".

Dengan paruhnya Bangau tong-tong itu mengangkat si Ketam. Lalu Bangau itu terbang. Gemetar ketakutan Ketam itu dalam jepitan paruh Bangau yang tajam. Sekuat tenaga ia berpegangan.

Mendekati bukit yang dituju, alangkah terkejutnya si Ketam. Ia tak melihat telaga atau genangan air barang setitikpun. Yang dilihat Ketam sungguh mengerikan. Gundukan tulang-belulang ikan yang menggunung.

Sadarlah Ketam, ia dan teman-temannya telah tertipu. Si Bangau tong-tong telah membawa ikan dari telaga untuk dimakan. Kian kecutlah hati si Ketam.

Dalam ketakutannya, timbul kemarahan di hati si Ketam. Dengan kuat ia menjepit leher si bangau. Terperanjat bangau kesakitan. Ia berusaha meronta. Namun kedua jepit si ketam kian kuat menjepit lehernya. Si Bangau tong-tong mencoba berteriak, namun tak mampu.

Akhirnya leher si Bangau tong-tong putus dijepit si Ketam. Bangau itu pun jatuh dan mati. Sedang si Ketam yang tubuhnya bercangkang keras hanya memar saja saat ia terbanting di rerumputan.

Dengan sedih si Ketam masuk ke sebuah kubangan kecil. Ia telah kehilangan semua temannya. Kini ia harus hidup sendirian di tempat yang baru. (Jakarta.go.id)

\section{Translated}

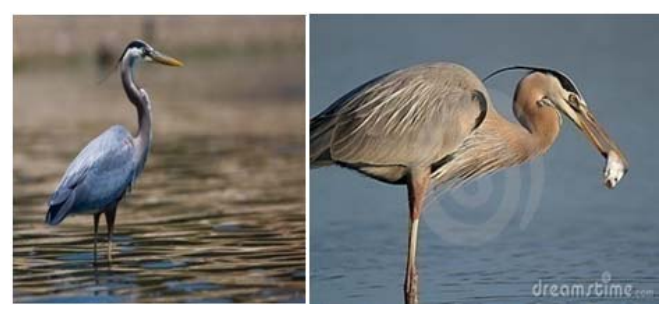

Figure 1 The Sly Old Stork 
On top of the shade tree branches, the old Stork saw many big and little fishes that were swimming cheerfully in that clear water. The old Stork was very hungry, but he was too old to hunt fish in that clear lake. Suddenly, the old Stork beak looked up into the sky. He just got a sly idea; that was to get the fishes without having to chase them.

"Hi friends,” the old Stork cried, "The drought will soon arrive."

"Heh, what do you care?" said the Snakehead fish.

"Everyone knows that drought will come," said the Crab.

"Do not listen to that silly old Stork" the Cat Fish said sharply.

"Wait comrades," said Stork, "The drought will last a long time, this lake will dry up".

"Whaaat?" cried all the lake fishes.

"Yes comrades, this lake will dry up".

Fear came upon all the inhabitants of the lake. They were crying, gathering their families, and somewere collecting their belongings. They all swam aimlessly.

"Be calm comrades," said the old Stork, "I know a vast lake at the foothills, the lake never dries even in a very long drought."

"What Lake?", “a Carp snapped," Do you think we will fly there? "

"That's what I'm talking about, my friends," said the old Stork, "If you like, I can take you one by one to fly there"

"Really?" welcomed the Goldfish.

"Of course," replied the old Stork," I will help you, friend."

"Take us uncle, take us," cried the animal inhabitants of the lake noisily.

"Quiet-quiet, no need to fight. I will bring you one by one."

Then the Stork came to the groups of fishes. With his beak he lifted a magnitude Goldfish. Then, he flew the carp in its beak. All day repeatedly he took the fishes and other aquatic animals from the lake. At dusk, all the fish had been lifted out. Only the Crab who was left alone.

The Crab looked left and right. There was no one else friends. He thought that his friends have been happy in a big lake in the foothills, as the Stork promised. Soon, the Stork back. He looked around, there was no longer visible fish. The Stork smiled contentedly, she had a full stomach. He then landed on a tree branch.

"Uncle Stork, do not forget me", a hoarse voice woke up the Stork.

"Hmm, is that you, Crab?" said the Stork.

"Yes uncle, take me also in your lake, please uncle here, I am alone now."

The Stork was staring the Crab. The creature just had a little meat, of course. And, he was full. He had eaten all of the lake fishes. However, the Stork was greedy, and he thought it was quite delicious to eat Crab for dessert.

"Alright little buddy," said the Stork, "Let me take you to my lake".

With her beak, the Stork picked up the Crab and flew fast. The Crab stayed fearfully in the Stork's beak by holding tightly his sharp tongs. He was desperately clinging to the beak. Approaching the hill, the Crab was surprised. He did not see any single fish in the lake. Instead, he saw a mount of fishes' bones. The Crab was horrific, he realized the he and his friends had been deceived by the stork. The old Stork had brought all the fishesfrom the lake to eat, not to be moved into the new lake. The Crab felt more desperate.

In fear, anger arised in the heart of the Crab. Strongly, the Crab pinched the neck of the old Stork. Startled in pain, the stork tried to wriggle. However, both of the crab's powerful jaws clamped around his neck. 
The Stork tried to scream but he could not. Finally, the neck of the Stork was broken, and he fell down and died. Having the hard-shelled crab, he only bruised his body just as he slammed on the grass.

Sadly, the Crab went into a small puddle. He had lost all his friends. Now he had to live alone in a new place. (Jakarta.go.id)

After translating the text, there is a glossary to introduce vocabularies in the reading. The glossary is presented in pictures, the Indonesian names, the English names, and the synonyms (if any). The purpose of it is to clarify the characters and to develop students' vocabularies in the story's context. It can be seen in Table 1.

Table 1 The Glossary of Vocabularies

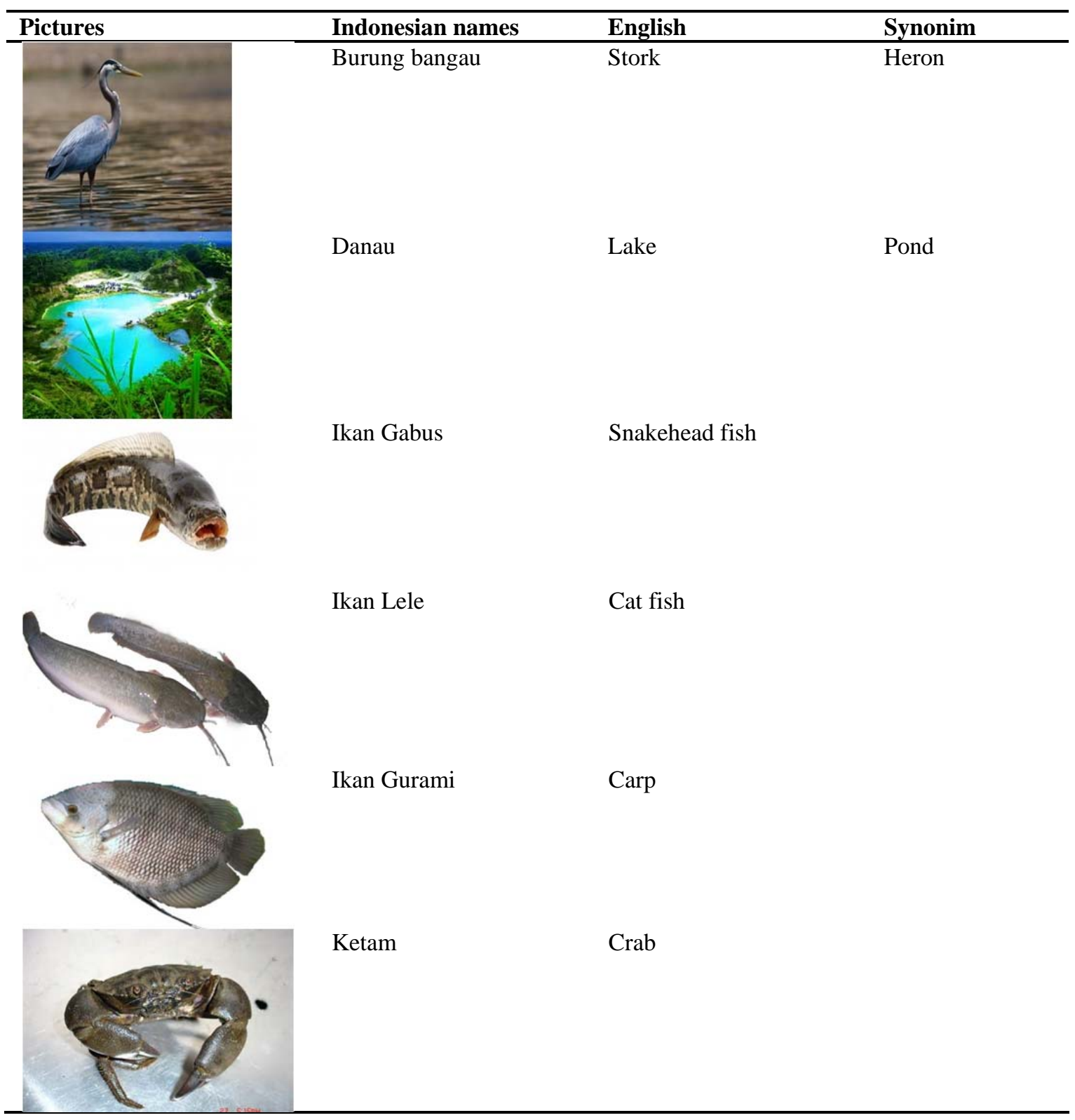


Table 1 The Glossary of Vocabularies (Continued)

\begin{tabular}{|c|c|c|c|}
\hline Pictures & Indonesian names & English & Synonim \\
\hline & Ikan emas & Goldfish & \\
\hline & Paruh Bangau & Stork's beak & \\
\hline
\end{tabular}

After understanding the glossary, there will be exercises to develop student's comprehension and skill of writing.

\section{Exercise I (Table 2)}

Look at the picture and say it in English. The purpose of it is to make sentences based on the pictures and jumble words.

Table 2 Making Sentences from Picture and Jumble Words

\begin{tabular}{lll}
\hline Po & Jumble words & Sentences \\
\hline 1 & $\begin{array}{l}\text { the Stork - branch of tree- standing - } \\
\text { is-on }\end{array}$ & $\begin{array}{l}\text { The Stork is standing on a } \\
\text { branch of a tree. }\end{array}$ \\
the fishes - the lake - are - & The fishes are swimming \\
in the lake
\end{tabular}


Table 2 Making Sentences from Picture and Jumble Words (Continued)

\begin{tabular}{|c|c|c|c|}
\hline No & Picture & Jumble words & Sentences \\
\hline 5 & & $\begin{array}{l}\text { the Stork's neck - pinching - is-the } \\
\text { Carb }\end{array}$ & $\begin{array}{l}\text { The Crab is pinching the } \\
\text { Strork's neck }\end{array}$ \\
\hline 6 & & $\begin{array}{l}\text { Moves-near lake - the - to-the } \\
\text { fishes- the Stork }\end{array}$ & $\begin{array}{l}\text { The Stork moves the } \\
\text { fishes to the near lake }\end{array}$ \\
\hline
\end{tabular}

Exercise II: Participating in Group Discussion

Look at the photographs. Work with a partner to make notes about similarities and differences between the two pictures. It can be the colours, size, characteristics, and anything related to the pictures.

\section{Picture 1}
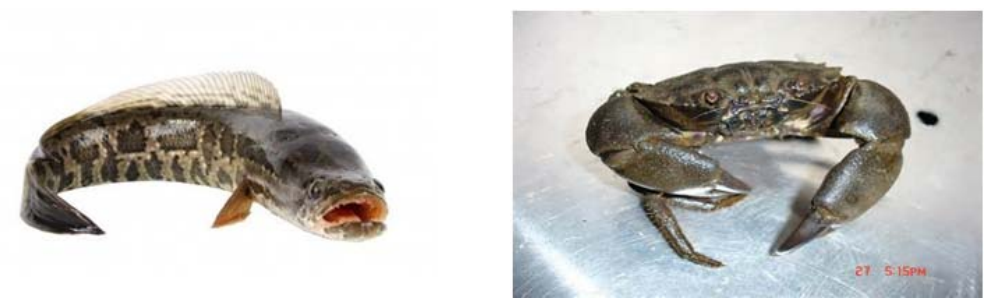

The first picture is

The second picture is

Similarities:

Differences:

\section{Picture 2}
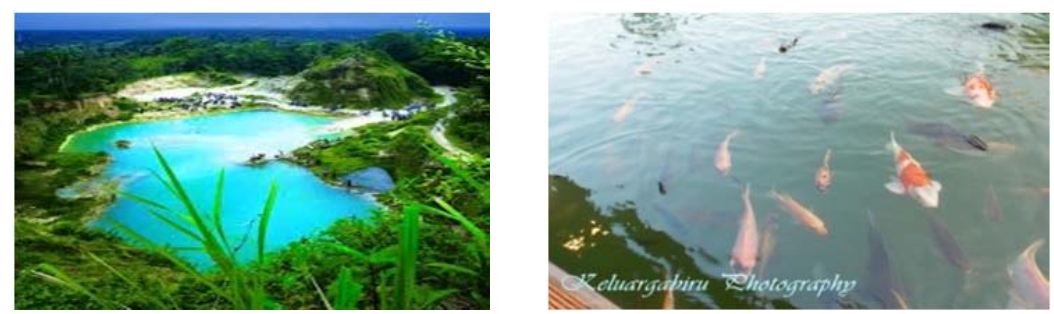

The first picture is

The second picture is

Similarities:.

Differences: 
Exercise III: Introducing Question Words (Table 3)

Who (Siapa)

What (Apa):

When (Kapan)

Where (Di mana/kemana)

Why (Mengapa)

Look at the example and make your own questions and answer them.

Table 3 Questions Words to Comprehand the Story

\begin{tabular}{|c|c|c|}
\hline Question Words & Questions & Answer \\
\hline Who (siapa?) & $\begin{array}{l}\text { Who is seeing many fishes swimming } \\
\text { in the lake? }\end{array}$ & $\begin{array}{l}\text { The Stork is seeing many fishes } \\
\text { swimming in the lake. }\end{array}$ \\
\hline \multicolumn{3}{|c|}{ 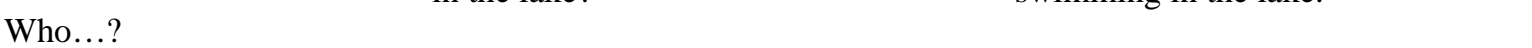 } \\
\hline \multicolumn{3}{|l|}{ Who ...? } \\
\hline What (apa?) & What is the Stork doing? & $\begin{array}{l}\text { The Stork is perching on a branch of } \\
\text { a tree. }\end{array}$ \\
\hline \multicolumn{3}{|l|}{ What...? } \\
\hline \multicolumn{3}{|l|}{ What...? } \\
\hline When (kapan?) & When will the drought come? & $\begin{array}{l}\text { The drought will come soon in the } \\
\text { lake. }\end{array}$ \\
\hline \multicolumn{3}{|l|}{ When... } \\
\hline \multicolumn{3}{|l|}{ When... } \\
\hline Where (di mana/kemana) & $\begin{array}{l}\text { Where does the Strok want to move } \\
\text { the fishes? }\end{array}$ & $\begin{array}{l}\text { The Stork moves the fishes to a vast } \\
\text { lake at the foothills. }\end{array}$ \\
\hline \multicolumn{3}{|l|}{ Where...? } \\
\hline \multicolumn{3}{|l|}{ Where ...? } \\
\hline Why (mengapa?) & Why is the crab angry? & $\begin{array}{l}\text { The crab is angry because the Stork } \\
\text { eats all of fishes. }\end{array}$ \\
\hline \multicolumn{3}{|r|}{ ent } \\
\hline Why ...? & & \\
\hline
\end{tabular}

\section{CONCLUSIONS}

The process of compiling reading materials can be conducted by the following sequences: selecting the folklore presenting Betawi culture and suitable for the fifth year of primary school students. Burung Bangau yang Licik is chosen because it belongs to Betawi folklore, that is fable, a story with animal character, translating the chosen reading materials to be a simplified reading suitable for the respondent, adding pictures describing animal character and place setting to make the reading materials easy to understand, and adding glossary to make easy the reading comprehension. The process of making reading exercises can be done by vocabulary in context method. After doing the first exercise containing simple sentence building, the next exercise will be on the writing to make a comparison between the two objects. 
The development of writing skills of the 5th year of primary school students can be done by introducing the questions words: Who, What, Where, When, and Why. The skills of the compiling

complete answer will support students to achieve their writing skills.

\section{REFERENCES}

Ackerman, T. (1994). Storytelling: A Way of Freeing the Imagination: An Interview with DvoraShurman. The Journal of the Imagination in Language Learning and Teaching, 2. Retrieved December 31, 2003 from http://www.njcu.edu/cill/journal-index.html.

Anderson, N. J. (2003). Scrolling, Clicking, and Reading English: Online Reading Strategies in a Second/Foreign Language. The Reading Matrix, 3(3), 1-33.

Brown, H. D. (2001). Teaching by Principles An Interactive Approach to Language Pedagogy (Second Edition). New York: Longman.

Burhan, N. (2005). Sastra Anak, Pengantar Pemahaman Dunia Anak. Yogyakarta: Gadjah Mada University Press.

Desi, A. (2013, November $9^{\text {th }}$ ). A Reading Habit. The Jakarta Globe. Retrieved from www.thejakartaglobe.com/opinion/desi-anwar-a-reading-habit/

Dursin, R. L. (2009, November 29 th $^{\text {th }}$. Developing Children Reading Habit. The Jakarta Post. Retrieved from www.thejakartapost.com/news/2009/11/29/developing-chilren-039s-readinghabits.html.

Hendra, W. (2013, July 10 ${ }^{\text {th }}$ ). Cublak-cublak Suweng, Dunia Anak Indonesia yang Jujur. Kompasiana. Retrived from http://www.kompasiana.com/wardhanahendra/cublak-cublak-suweng-duniaanak-indonesia-yang-jujur_552e4eaa6ea834e0418b457a.

Supartinah. (2007). Tiyang Tanilan Tikus: Mewariskan Nilai Budi Pekerti Bagi Anak Melalui Dongeng Klasik Jawa. Diksi FBS UNY 14 (2). ISSN 0854 - 2937.

Wahyuni. (2014). Mastering English is the Solution to Strengthen Competitive Skills in Free Trade. Retrieved from www.voiceofyouth.org/en/posts/mastering-English-is-the-solution-tostrenghten-competitive-skills-in-free-trade/ 